\title{
Hubungan Openness to Experience terhadap Perilaku Kerja Inovatif: Peran Ambidextrous Organization Culture sebagai Moderator
}

\author{
Brianita Riga Pratiwi, Alice Salendu \\ Program Studi Psikologi, Fakultas Psikologi, Universitas Indonesia, Depok
}

Abstrak: Pada era ini, bagaimana membentuk karyawan yang inovatif merupakan tantangan dan penting bagi organisasi untuk mengetahui factor yang menjadi penyebab perilaku inovatif pada karyawannya. Penelitian ini melibatkan tiga variable yaitu kepribadian openness to experience, organizational ambidextrous culture, dan perilaku kerja inovatif. Dengan menggunakan 3 alat ukur yaitu The Big Five Personality Inventory (BFI), innovative behavior scale, dan ambidextrous organizational scale, sebanyak 127 responden diperoleh dengan metode pengambilan self-report secara daring. Peneliti menguji peran moderasi dari organizational ambidextrous culture yang dianalisis dengan teknik statistic PROCESS yang dikembangkan oleh Hayes. Hasil penelitian menunjukkan hubungan positif antara openness to experience (OTE) dan ambidextrous organizational culture terbukti secara signifikan menjadi predictor dari perilaku kerja inovatif karyawan $\mathrm{F}=25.1475, p<.001, \mathrm{R}^{2}=.3840$. Dari hasil tersebut, dapat dinyatakan sebanyak $38.4 \%$ varians dari kedua predictor tersebut secara signifikan berpengaruh terhadap munculnya perilaku kerja inovatif. Namun, melalui hasil analisa juga diketahui bahwa tidak terdapat efek interaksi yang signifikan pada variabel ambidextrous organizational culture, sehingga hipotesis 1 diterima, namun hipotesis 2 tidak diterima. Hasil penelitian ini dapat memberikan gambaran pada berbagai perusahaan dalam melakukan rekrutmen pada karyawan baru untuk mempertimbangkan calon karyawan yang memiliki kepribadian yang openness.

Kata Kunci: budaya organisasi, kepribadian, perilaku kerja inovatif, openness to experience

\section{Relationship between Openness to Experience and Innovative Behaviour: The role of Ambidextrous Organizational Culture as Moderator}

Abstract: In this era, how to form employees is a challenge and important for innovative organizations to see the factors that cause innovative behavior in their employees. This study involved three variables, namely openness to experience, ambidextrous organizational culture, and innovative work behavior. By using 3 measuring instruments, namely The Big Five Personality Inventory (BFI), Innovation Behavior Scale, and Ambidextrous Organizational Scale, as many as 127 respondents were obtained using the bold self-report method. Researchers examined the moderating role of ambidextrous organizational culture as analyzed by the PROCESS statistical technique developed by Hayes. The results showed a positive relationship between OTE and ambidextrous organizational culture was proven to be a significant predictor of employee innovative work behavior. $\mathrm{F}=25.1475, p<.001, \mathrm{R}^{2}=.384$. From these results, it can be calculated that $38.4 \%$ of variants of the two predictions have a significant effect on innovative work behavior. However, through the analysis it is also known that there is no significant interaction between the ambidextrous organizational culture variables, thus the first hypothesis is accepted but not the second hypothesis. The result of this research can help companies to identify the openness traits of the prospective employees.

Keywords: ambidextrous organizational culture, innovative behaviour, openness to experience, organization culture

Korespondensi: Alice Salendu. Email: alice.salendu@ui.ac.id 
Revolusi industri 4.0 membuat perusahaan saling berkompetisi untuk melakukan digitalisasi agar mampu bertahan dalam persaingan bisnis. Salah satu elemen utama yang memberikan dampak besar bagi industri konvensional menuju industri digital adalah teknologi (Zhou et al., 2005). Perkembangan teknologi yang diiringi dengan derasnya arus informasi dan lingkungan yang dinamis menuntut perusahaan untuk terus memiliki strategi inovasi yang tepat dalam menjalankan proses bisnisnya. Daya saing dan kelangsungan hidup yang dimiliki oleh organisasi bergantung pada bagaimana mereka mampu untuk mengelola inovasinya (Palangkaraya et al., 2010). Inovasi dapat berupa penciptaan nilai sebagai sumber keunggulan kompetitif bagi perusahaan (Jiangtao Shi, 2012). Menurut Javed et al (2019), inovasi penting untuk terus dilakukan karena kurangnya inovasi akan menyebabkan bisnis dapat mengalami kegagalan bisnis. Banyaknya organisasi yang gagal karena kurang inovatif membuat organisasi perlu meningkatkan kinerjanya untuk memunculkan perilaku inovatif pada karyawan. Sejalan dengan itu, Yuan \& Woodman (2010) menyatakan bahwa perilaku inovatif merupakan inovasi dalam level individu yang berguna untuk efektivitas dalam suatu organisasi.

Berbagai penelitian telah dilakukan yang menyatakan bahwa perilaku kerja inovatif merupakan sebuah penentu penting yang efektif bagi organisasi dalam menghadapi tantangan baru (Yuan \& Woodman, 2010). Ide atau inovasi baru dari karyawan dapat meningkatkan pelayanan dan efisiensi; berperan penting dalam kesuksesan organisasi (West \& Farr, 1989), dan juga merupakan aset bagi organisasi (Perkonigg et al., 2008) . Hasil penelitian lain menyebutkan bahwa perilaku inovatif memiliki efek jangka panjang yang akan berguna untuk meningkatkan keuntungan bagi organisasi dalam jangka waktu yang lama (Janssen, 2000).

Perilaku kerja inovatif dapat diartikan sebagai perilaku memulai dan menerapkan ideide baru yang meliputi proses, produk, dan prosedur dalam bekerja (West \& Farr, 1989). Perilaku kerja inovatif digambarkan dengan perilaku individu yang mengarah pada penciptaan, pengenalan ide baru dalam peran kerja, kelompok, ataupun organisasi (de Jong \& den Hartog, 2010). Inovasi yang ditunjukkan oleh individu dapat dilihat dari kecenderungan karyawan untuk terlibat dalam perilaku extrarole yang dapat bermanfaat dan berpengaruh terhadap meningkatnya efektivitas dalam organisasi (Scott \& Bruce, 1994).

Penelitian terdahulu telah menguji faktorfaktor internal maupun eksternal yang dapat memprediksi perilaku inovatif. Adapun faktor internal yang dapat mendorong munculnya perilaku inovatif diantaranya adalah kepribadian, kemampuan interpersonal individu dan juga perilaku proaktif individu (Jong \& Hartog, 2007). Sementara terdapat juga 
faktor eksternal yang dapat mendorong seseorang memunculkan perilaku inovatif seperti budaya organisasi, pengaruh tempat kerja, karakteristik pekerjaan, tingkat pendidikan, kepemimpinan, kualitas hubungan antara atasan dengan bawahan.

Kepribadian merupakan faktor internal individu yang dapat berkontribusi pada munculnya perilaku tertentu, termasuk dalam individu bekerja (Yesil \& Sozbilir, 2013). Kepribadian merupakan anteseden penting dari perilaku kerja inovatif yang berpengaruh dalam performa dan kesuksesan dalam organisasi. Sejalan dengan itu, Madrid et al (2014) juga menjelaskan bahwa faktor kepribadian dapat mendorong seseorang untuk memunculkan, mempromosikan ide-ide baru.

Berbagai penelitian telah meneliti hubungan ciri dari kepribadian tertentu dengan perilaku inovatif (Javed et al, 2019). Namun, pada beberapa hasil penelitian mengenai individual differences dalam perilaku kerja inovatif ditemukan hasil yang tidak konsisten pada hubungan antara kepribadian dengan perilaku inovatif di tempat kerja (Madrid et al., 2014; Woods et al., 2018). Beberapa penelitian lain yang menghubungan kepribadian dan perilaku inovatif memiliki beberapa kekurangan utama seperti masalah konseptualisasi, masalah generalisasi, fokus pada inovasi organisasi (Yesil \& Sozbilir, 2013). Masih terdapat gap dari hasil penelitian sebelumnya sehingga peneliti merasa perlu untuk menguji lebih lanjut hubungan keduanya.
Peneliti akan berfokus pada faktor internal yaitu kepribadian dimana merupakan faktor yang dapat mendorong munculnya perilaku kerja inovatif pada individu (West \& Farr, 1989). Kepribadian yang akan digunakan dalam penelitian ini adalah big five dengan berfokus pada tipe openness to experience. Hal ini didasarkan karena pada penelitian terdahulu, tipe kepribadian ini yang secara konseptual paling berhubungan dengan perilaku kerja yang inovatif dan konsisten di identifikasi sebagai prediktor pada perilaku inovatif (Javed et al., 2019; Woods et al, 2018). Menurut DeYoung et al (2014) kepribadian openness merupakan satu-satunya faktor yang secara konsisten dan terkait dengan kreativitas, gaya berpikir, yang mengarah pada perilaku inovatif. Mengacu pada hasil tersebut, dijelaskan bahwa karyawan dengan openness yang tinggi akan aktif mengeksplorasi, mempromosikan, dan menerapkan ide-ide baru yang menunjukkan parilaku inovatif (Madrid et al, 2014).

Selain faktor internal, berdasarkan penelitian terdahulu budaya juga memiliki peran penting dalam menghasilkan perilaku inovatif (Jong \& Hartog, 2007). Budaya organisasi berperan sebagai sistem kendali, yang mengandung nilai-nilai yang menjadi pedoman tindakan anggota dalam organisasi (Büschgens et al, 2013). Dari penjelasan di atas, diketahui bahwa peran organizational culture telah banyak dihubungkan dengan perilaku kerja inovatif, namun budaya ambidextrous dalam organisasi belum banyak dilakukan (Liu et al, 2019). 
Ambidextrity merupakan jenis budaya organisasi yang menunjukkan kreativitas dan disiplin pada saat yang bersamaan dan dapat membantu untuk eksplorasi dan eksploitasi untuk memfasilitasi inovasi (Gibson \& Birkinshaw, 2004). Menurut Wang \& Rafiq (2014) ambidextrous culture tediri dari dua dimensi yaitu organizational diversity dan shared vision. Penelitian yang menekankan pada pentingnya budaya ambidextreous dalam organisasi telah ditemukan secara empiris namun masih sangat terbatas (Gibson \& Birkinshaw, 2004; Khan \& Mir, 2019; Lau et al, 2019; Liu et al., 2019). Padahal dari hasil penelitian Wang \& Rafiq (2014) menjelaskan bahwa ambidextrous organizational culture memiliki peran terhadap munculnya perilaku inovasi karena mencakup aspek organizational diversity yang dapat memunculkan ide-ide baru.

Berbagai studi tentang hubungan kepribadian dengan perilaku kerja inovatif telah menunjukkan pengaruh positif kepribadian terhadap perilaku kerja inovatif (Woods et al, 2018; Wortman et al., 2012). Namun studi lainnya menunjukkan hasil yang tidak konsisten terhadap perilaku inovatif sehingga membutuhkan moderator seperti ethical leadership (Javed et al., 2019), masa kerja (Woods et al., 2018); budaya (Wang \& Rafiq, 2014) pada hubungan openness to experience dengan perilaku kerja inovatif. Dengan demikian, asumsi bahwa openness to experience merupakan prediktor yang paling penting dari perilaku kerja inovatif (DeYoung et al., 2014), perlu dijelaskan lebih lanjut untuk melihat pengaruh dari variabel lain yaitu ambidextreous organizational culture yang dapat menguatkan hubungan antara openness to experience dengan perilaku kerja inovatif.

Perilaku kerja inovatif merupakan sebuah penerapan ide baru dalam melakukan pekerjaan, grup, atau organisasi yang memiliki tujuan untuk menguntungkan performa peran organisasi (West \& Farr, 1989). Pada penelitian Janssen (2000) menyatakan bahwa perilaku kerja inovatif dapat dilihat dari serangkaian perilaku yang berkaitan dengan aplikasi penciptaan ide baru dalam bekerja sesuai perannya dalam kelompok atau organisasi. Perilaku kerja inovatif biasanya meliputi eksplorasi dan generasi dari ide-ide yang dapat mencakup perilaku yang menerapkan pengetahuan baru atau memperbaiki proses dalam meningkatkan performa kerja pribadi maupun bisnis (Jong \& Hartog, 2007). Menurut Scott \& Bruce (1994) perilaku kerja inovatif terdiri dari tiga tahapan, yaitu idea generation, idea promotion, dan idea realization. Perilaku kerja inovatif dimulai dengan tahapan idea generation dimana seseorang akan mulai memproduksi hal baru dan ide yang berguna ketika dihadapkan pada masalah. Pada tahapan selanjutnya yaitu idea promotion, individu akan mulai mempromosikan ide yang potensial dengan mencari dukungan untuk mendapatkan kekuatan dalam mewujudkan idenya. Pada tahap terakhir yaitu idea realization, ditandai 
dengan penerapan dan aplikasi ide dalam peran kerja, kelompok, atau organisasi.

Seperti yang telah disebutkan, faktor kepribadian merupakan salah satu faktor yang menjadi pendorong munculnya perilaku inovatif (Javed et al, 2019). Mengacu pada teori Big Five Personality, dijelaskan bahwa openness to experience merupakan salah satu dimensi yang pada umumnya digambarkan dengan individu yang imajinatif, memiliki wawasan luas, cerdas, artisitk, berbudaya. Seseorang yang memiliki openness yang tinggi akan memiliki fleksibilitas dalam berpikir, memiliki rasa ingin tahu, keatif, imajinatif (Costa \& McCrae, 1992). Opennes to Experience menunjukkan kecenderungan untuk mendapatkan pengalaman baru yang beragam dengan melibatkan berbagai pemikiran dan ideide (Costa \& McCrae, 1992). Oleh karena itu openness merupakan salah satu prediktor penting dalam perilaku kerja inovatif karena selalu terbuka pada pengalaman baru dan perubahan (Scott \& Bruce, 1994).

Berbagai penjelasan di atas didukung oleh beberapa hasil penelitian yang menemukan hubungan positif antara opennesss to experience dengan perilaku kerja inovatif (Javed et al, 2019; Madrid et al,, 2014; Scott \& Bruce, 1994). Individu yang terbuka akan menunjukkan keingintahuan yang mengarah pada pemikiran inovatif tinggi menghasilkan berbagai ide dan perspektif. Selain itu, orangorang yang openness merupakan individu kreatif yang selalu memilih pekerjaan yang bevariasi daripada yang bersifat rutinitas (Yesil \& Sozbilir, 2013). Sejalan dengan pernyataan tersebut, menurut Janssen (2000) perilaku kerja inovatif dicirikan oleh generasi, promosi, aplikasi ide-ide baru yang dimiliki oleh karyawan yang memiliki sifat dalam kepribadian openness to experience. Oleh karena itu dapat dikatakan bahwa seseorang yang memiliki openness yang tinggi akan mengarah pada perilaku kerja inovatif yang lebih besar. Berdasakan penjelasan tersebut peneliti mengajukan hipotesis sebagai berikut:

Hipotesis 1 : Openness to Experience berhubungan positif dengan perilaku kerja inovatif.

Budaya merupakan faktor eksternal yang mendorong seseorang untuk memunculkan dan merealisasikan ide ide (Jong \& Hartog, 2007). Menurut Wang \& Rafiq (2014), ambidextreous organisational culture merupakan budaya yang lebih pro pada perilaku inovatif karena melibatkan keterlibatan dan partisipasi individu. Ambidextrity merupakan jenis budaya organisasi yang menunjukkan kreatifitas dan disiplin pada saat yang bersamaan dan dapat membantu untuk eksplorasi dan eksploitasi untuk memfasilitasi inovasi (Gibson \& Birkinshaw, 2004).

Menurut Blickle et al (2013), konteks yang tepat akan memotivasi karyawan untuk mengaktifkan ciri-ciri kepribadiannya. Dalam hal ini peneliti berasumsi bahwa budaya ambidextreous culture merupakan konteks 
yang tepat untuk menguatkan hubungan antara openness to experience dengan perilaku kerja inovatif. Dengan kata lain, dalam organisasi yang menerapkan budaya ambidextreous, akan lebih mungkin bagi karyawan untuk memunculkan perilaku kerja inovatif yang ditunjukkan dari sifat openness to experience yang dimiliki.

Ambidextrous organizational culture terdiri dari dua dimensi yaitu organization diversity dan shared vision. Organization diversity mencakup nilai dan norma pada organisasi yang mendukung dan mendorong diversity, termasuk dalam toleransi dalam perbedaan sudut pandang. Shared vision mencakup nilai dan norma yang mempromosikan keterlibatan karyawan dalam pengembangan, komunikasi, dalam implementasi tujuan organisasi dan dalam menyusun pekerjaan (Wang \& Rafiq, 2014).

Hubungan antara ketiga variable openness to experience, perilaku kerja inovatif, dan ambidextrous organizational culture dapat dijelaskan melalui self determination theory. Mengacu pada self-determination theory yang disampaikan oleh Ryan et al (2008), dijelaskan bahwa karyawan akan termotivasi bertindak dan memunculkan inovasinya berdasarkan seberapa terpenuhinya kebutuhan psikologis mereka. Teori ini berfokus pada bagaimana faktor kontekstual akan mendukung pemenuhan kebutuhan dasar psikologis seorang individu. Ketiga kebutuhan dasar psikologis meliputi kebutuhan kompetensi (competence), otonomi (autonomy), dan keterhubungan (relatedness) dimana ketiga kebutuhan dasar ini merupakan aspek yang sangat penting untuk perkembangan diri (Ryan et al., 2008).

Mengacu pada penjelasan di atas, dapat dikatakan ketika karyawan mempersepsikan tingkat ambidextreous organizational culture yang lebih tinggi, karyawan merasa memiliki kesempatan untuk lebih terbuka dalam mengeksplorasi ide dan hal-hal baru sehingga menjadi lebih fleksibel dalam berpikir, memiliki rasa ingin tahu dan kreatif dalam berimajinasi (Costa \& McCrae, 1992). Semakin karyawan tersebut menunjukkan kepribadian openness dengan lebih terbuka terhadap pengalaman dan perubahan baru, selanjutnya akan berkontribusi pada munculnya perilaku inovatif.

Dengan demikian, dapat dikatakan bawa semakin individu mempersepsikan organisasinya menerapkan budaya ambidextrous, individu tersebut akan lebih merasa memiliki kesempatan untuk lebih terbuka dalam mengeksplorasi ide-ide dan pengalaman baru dan memunculkan perilaku inovatif dalam bekerja.

Dari berbagai penjelasan tersebut, peneliti mengajukan hipotesis sebagai berikut:

$\mathrm{H} 2$ : Ambidextrous organizational culture memoderasi hubungan antara openness to experience dan perilaku kerja inovatif. 


\section{Gambar 1}

Model Penelitian

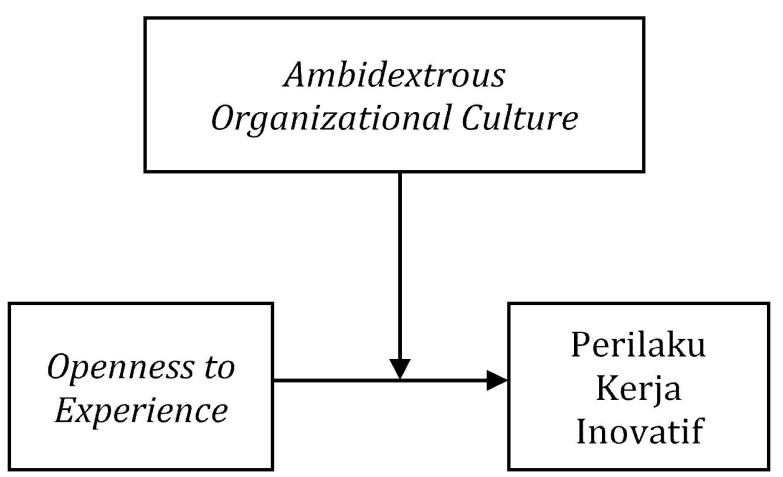

Berdasarkan berbagai penjelasan dan argument di atas, peneliti ingin menyelidiki lebih lanjut mekanisme yang mendasari bagaimana kepribadian opennesss to experience dapat menjadi penyebab perilaku kerja yang inovatif yang dimoderatori oleh ambidextrous organizational culture. Kontribusi yang akan diberikan oleh penelitian ini adalah melengkapi hasil penelitian sebelumnya terkait ambidextrous organization culture dan mengeksplorasi perannya sebagai moderator.

\section{Metode}

Penelitian ini menggunakan pendekatan kuantitatif yang dilakukan untuk menguji hubungan variabel. Penelitian ini juga merupakan penelitian korelasional, yang bertujuan untuk menggambarkan hubungan antara dua variabel dan merupakan penelitian non-eksperimental. Desain penelitian adalah cross-sectional dimana penelitian dilakukan dalam satu waktu. Adapun teknik pengambilan sampel adalah non-probability sampling dimana teknik akan digunakan ketika distribusi dan jumlah populasi tidak diketahui.

Pengambilan data dilakukan dengan instrument penelitian berupa self report secara daring dengan menggunakan google form. Sampel dari penelitian dipilih berdasarkan karakteristik demografis dengan metode pengumpulan kuesioner. Sampel dari penelitian ini adalah karyawan di berbagai sektor atau bidang pekerjaan. Hal ini dilakukan dengan maksud agar penelitian ini memiliki sampel yang bervariasi sehingga tidak terbatas pada beberapa jenis pekerjaan tertentu.

Teknik pengambilan sampel yaitu convenience sampling yang didasarkan pada ketersediaan elemen dan kemudahan untuk mendapatkannya, karena penelitian akan dilakukan secara online. Proses pengambilan data diawali dengan menghubungi kerabat yang dikenal karena paling mudah untuk didapatkan. Peneliti juga menghubungi calon responden yang sesuai dengan karakteristik partisipan melalui whatsapp, line, dan direct message Instagram. Selanjutnya, kuesioner diberikan 
kepada sejumlah responden melalui media sosial seperti email, whatsapp, line, atau direct message Instagram.

Responden dari penelitian ini adalah karyawan di perusahaan dengan masa kerja minimal satu tahun. Alasan pemilihan partisipan dengan masa kerja minimal satu tahun dikarenakan partisipan sudah merasakan dan mengetahui kondisi pekerjaan dan lingkungan dalam perusahaan tempat mereka bekerja. Selain itu, masa kerja (tenure) juga merupakan aspek yang dianggap memiliki relevansi untuk mengetahui performa kerja karyawan (Liu et al., 2019).

\section{Tabel 1}

Karakteristik Demografis

\begin{tabular}{lcc}
\hline \multicolumn{1}{c}{ Karakteristik } & $n$ & $\%$ \\
\hline Jenis Kelamin & 53 & \\
Laki-Laki & 72 & $42.4 \%$ \\
Perempuan & & $57.6 \%$ \\
Bidang Pekerjaan & 8 & \\
Pertambangan & 3 & $6.4 \%$ \\
Agraris & 21 & $2.4 \%$ \\
Industri & 11 & $16.8 \%$ \\
Retail & 82 & $8.8 \%$ \\
Jasa & & $65.6 \%$ \\
Pendidikan & 7 & \\
SMA/SMK & 25 & $5.6 \%$ \\
D1/D2/D3 & 83 & $20 \%$ \\
S1 & 10 & $66.4 \%$ \\
S2 & & $8 \%$ \\
Masa Jabatan & 100 & \\
<2 tahun & 72 & $56 \%$ \\
3-10 tahun & 7 & $40 \%$ \\
$>11$ tahun & & $4 \%$ \\
Sistem Kerja & 67 & \\
Full Time WFH & 58 & $53.6 \%$ \\
Full Time WFO & 81 & $46.4 \%$ \\
Shifting & & $45 \%$ \\
\hline
\end{tabular}

Catatan. $N=125$

Berdasarkan hasil pengambilan data dari tabel 1, didapatkan sampel sebanyak 127 karyawan dari berbagai bidang usaha di Indonesia, dan tersaring sebanyak 125 karyawan yang datanya di analisis lebih lanjut. Mayoritas sampel berjenis kelamin perempuan sebanyak 72 orang (57.6\%), dan 53 orang laki- laki (42.4\%). Pada kategori pendidikan terakhir, sampel terbanyak pada lulusan S1 yaitu sebanyak 83 orang (66.4\%), lulusan D1/D2/ D3 sebanyak 25 orang (20\%), lulusan S2 sebanyak 10 orang (8\%), dan lulusan SMA/SMK sebanyak 7 orang (5.6\%). Dari bidang pekerjaan, sampel terbanyak adalah karyawan 
yang bekerja di bidang jasa yaitu 82 orang (65.6\%), kemudian industri/manufaktur sebanyak 21 orang (16.8\%), retail sebanyak 11 orang (8.8\%), pertambangan sebanyak 8 orang (6.4\%), dan dan agraris sebanyak 3 orang $(2.4 \%)$.

\section{Prosedur penelitian}

Penelitian cross sectional dan self-report memiliki potensi terhadap munculnya common method bias yang dapat mempengaruhi dan mengacaukan hasil penelitian. Untuk mengatasi common method bias, langkah awal yang harus dilakukan peneliti adalah mengacak urutan butir dari masing-masing alat ukur. Setelah data terkumpul, dilakukan analisis deskriptif terhadap data demografis untuk melihat gambaran demografis partisipan. Kemudian analisis data dapat dilakukan.

\section{Pengukuran}

Instrumen pengukuran pada penelitian diukur dengan menggunakan skala Likert dengan lima alternatif jawaban dari (1) sangat setuju hingga (6) sangat tidak setuju. Ketiga instrumen pengukuran diperoleh dari jurnaljurnal yang menggunakan alat ukur ini sebelumnya dan telah dipublikasikan secara umum sehingga tidak memerlukan izin khusus dari pembuat alat ukur. Keseluruhan alat ukur telah diadaptasi ke Bahasa Indonesia dengan menggunakan back-translation.

\section{Openness to experience}

Openness to experience akan diukur menggunakan The Big Five Personality Inventory (BFI) untuk mengukur Big Five Personality. Dari yang 40 butir, yang akan digunakan dalam penelitian ini adalah 10 butir yang berfokus pada tipe kepribadian openness to experience. Adapun contoh butirnya adalah "Saya merasa ingin tahu tentang banyak hal yang berbeda" (á = .869).

\section{Perilaku Kerja Inovatif}

Alat ukur yang akan digunakan adalah skala yang dikembangkan oleh Janssen (2000) yang terdiri dari 9 butir. (á = .918). Innovative behaviour scale memiliki contoh butir "Saya menciptakan ide-ide baru untuk masalah yang sulit”.

\section{Organizational Ambidextrous Culture}

Variabel organizational ambidextrous organizational culture akan menggunakan alat ukur dari Wang \& Rafiq (2014) yang terdiri dari 7 butir. Pengukuran akan didasarkan pada persepsi karyawan bagaimana mereka memandang budaya organisasinya. Budaya ambidextrous dalam organisasi memiliki dua dimensi yaitu organization diversity dan shared vision. Organization diversity terdiri dari 3 butir dengan contoh butir seperti "Perusahaan kami menghormati perbedaan sudut pandang setiap karyawannya". Shared 
vision terdiri dari 4 butir dengan contoh butir "Semua karyawan dianggap sebagai rekan dalam merencanakan arah tujuan perusahaan ini”. Reliabilitas alat ukur yang dimiliki adalah .898 .

\section{Analisis data}

Analisis data diolah dengan metode kuantitatif menggunakan SPSS version of PROCESS yang hanya melibatkan satu variabel moderator dengan teknik moderation model (Hayes, 2013). Metode ini tepat digunakan dalam penelitian ini karena menurut Hayes (2013), process macro merupakan analisis yang menggunakan kerangka analisis jalur berbasis mediasi dan moderasi yang dikombinasikan menjadi conditional process model. Peneliti juga akan menambahkan analisis dari karakteristik demografis yang meliputi jenis kelamin, lama bekerja, pendidikan yang dikontrol dalam penelitian karena dianggap dapat mempengaruhi perilaku kerja inovatif pada karyawan.

\section{Hasil}

Hasil perhitungan karakteristik demografis telah disajikan pada tabel 2 . Berdasarkan table 2, hubungan antara openness to experience dengan perilaku kerja inovatif memiliki signifikansi yang cukup tinggi $(r=.578$, $p=.000)$. Hal ini menunjukkan bahwa secara statistik variabel openness to experience berperan signifikan untuk menjelaskan varian perilaku kerja inovatif. Nilai koefisien yang didapatkan sebesar .578 dapat diartikan setiap kenaikan satu nilai pada openness akan meningkatkan skor sebesar .578 pada perilaku kerja inovatif sehingga dapat disimpulkan bahwa hipotesis 1 yang diajukan oleh peneliti diterima. Arah korelasi yang ditunjukkan antara hubungan openness dengan perilaku kerja inovatif positif yang berarti semakin tinggi tingkat openness yang dimiliki karyawan maka akan semakin tinggi karyawan untuk melakukan perilaku kerja inovatif. Dengan demikian apabila karyawan memiliki kepribadian openness maka mereka akan semakin inovatif

\section{Tabel 2}

Mean, Standar Deviasi, dan Matriks Korelasi Antar Variabel

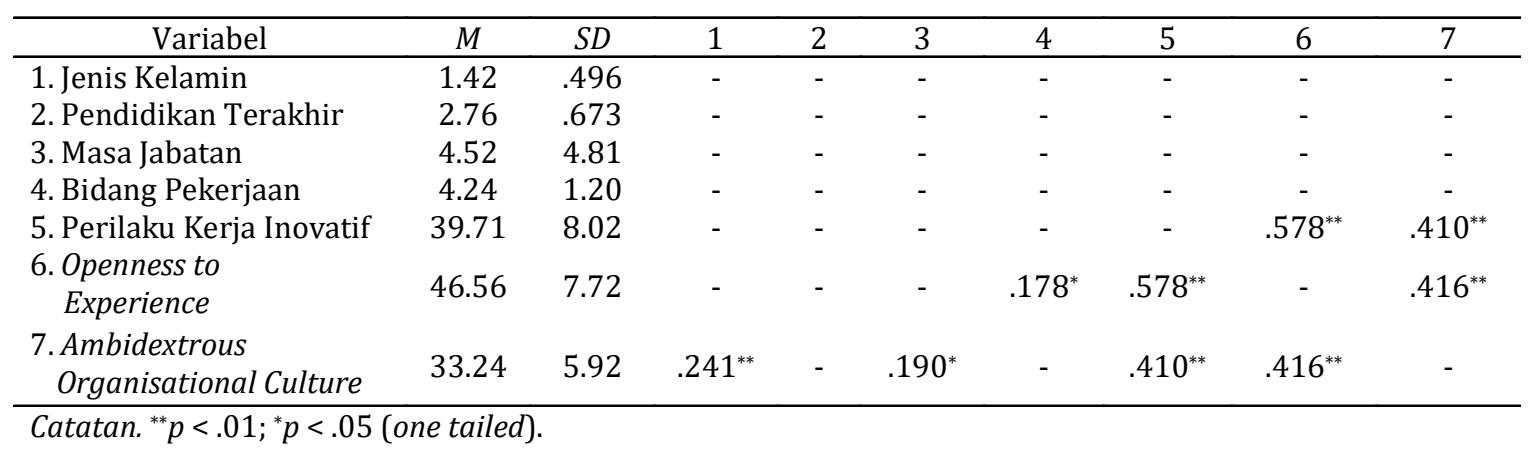


Setelah menguji peran dari variabel kontrol, ditemukan variabel yang dapat memperkuat atau memperlemah hubungan antara variabel perilaku kerja inovatif dengan openness to experience. Hasil analisis menunjukkan ternyata variabel bidang pekerjaan merupakan variabel yang memiliki pengaruh kuat terhadap hubungan variabel openness to experience dengan perilaku kerja inovatif menjadi $(r=.600, p=.000)$. Selain itu, variabel pendidikan terakhir juga berpengaruh signifikan dalam memperkuat hubungan menjadi $(r=.585, p=.000)$, dan masa jabatan menjadi $(r=.584, p=.000)$. Variabel yang lainnya yaitu jenis kelamin ditemukan memperlemah hubungan antara antara openness to experience dengan perilaku kerja inovatif $(r=.574, p=.000)$.

\section{Tabel 3}

Hasil Model Simpel Moderator

\begin{tabular}{|c|c|c|c|c|c|c|}
\hline & \multirow[b]{2}{*}{$B$} & \multirow[b]{2}{*}{$S E$} & \multirow[b]{2}{*}{$t$} & \multicolumn{2}{|c|}{$95 \% \mathrm{CI}$} & \multirow[b]{2}{*}{$p$} \\
\hline & & & & $L L$ & $U L$ & \\
\hline constant & 39.3752 & .6020 & 65.4098 & 38.1834 & 40.5670 & .0000 \\
\hline OTE & .5370 & .0828 & 6.4839 & .3731 & .7010 & .0000 \\
\hline$A O C$ & .2943 & .1067 & 2.7582 & .0831 & .5056 & .0067 \\
\hline Int_1 & .0178 & .0101 & 1.7547 & -.0023 & .0379 & .0818 \\
\hline
\end{tabular}

Catatan. $N=125$

Berdasarkan pengujian terhadap hipotesis penelitian dengan menggunakan PROCESS Hayes, didapatkan hasil bahwa variable openness to experience dan ambidextrous organizational culture terbukti secara signifikan menjadi predictor dari perilaku kerja inovatif karyawan $\mathrm{F}=25.1475$, $p<.001, \mathrm{R}^{2}=.3840$. Dari hasil tersebut, dapat dinyatakan sebanyak $38.4 \%$ varians dari kedua prediktor tersebut secara signifikan berpengaruh terhadap munculnya perilaku kerja inovatif. Namun, melalui hasil analisa juga diketahui bahwa tidak terdapat efek interaksi yang signifikan pada variabel ambidextrous organizational $(B=.0178, t(403)=1.754, p>$ .05). Hasil ini menunjukkan tidak adanya efek moderasi dari variable ambidextrous organizational culture terhadap hubungan antara kepribadian openness to experience dengan perilaku kerja inovatif pada karyawan. Dengan demikian dapat disimpulkan bahwa ambidextrous organizational culture tidak menguatkan hubungan antara openness to experience dengan perilaku kerja inovatif sehingga hipotesis 2 yang diajukan oleh peneliti ditolak.

\section{Pembahasan}

Penelitian ini menjelaskan hubungan antara kepribadian openness to experience, ambidextrous organization culture, dan perilaku kerja inovatif. Hasil temuan pada 
penelitian ini tidak menunjukkan peran variabel moderator yaitu organizational ambidextrous culture pada hubungan antara kepribadian openness to experience dengan perilaku kerja inovatif. Peran budaya organisasi bersama dengan openness to experience samasama sebagai variabel prediktor karena langsung berdampak pada perilaku kerja inovatif pada karyawan. Hal ini sesuai dengan penelitian tentang budaya organisasi dan inovasi dimana budaya merupakan faktor kontekstual yang dapat mempengaruhi inovasi terutama melalui dampaknya pada perilaku inovatif karyawan.

Berdasarkan teori self determination, dukungan dari ambidextrous organizational culture dapat mendorong karyawan untuk merasa memiliki kesempatan mendapatkan otonomi dalam tindakannya ketika bekerja sehingga memotivasi perilaku kerja yang inovatif (Liu et al, 2019). Ciri yang dimiliki oleh budaya ambidextrous juga mampu memberikan dukungan atas tantangan, kreativitas sehingga berujung pada perilaku inovatif karena karyawan memiliki kesempatan untuk mengeksplorasi kemampuan dan ide-ide baru dalam bekerja (Lee et al, 2019). Hal ini sejalan dengan hasil penelitian bahwa ambidextrous organizational culture dapat menjadi prediktor dari perilaku kerja inovatif. Namun ambidextreous organizational culture yang dipersepsikan karyawan tidak dapat membantu menguatkan pengaruh openness to experience terhadap innovative work behavior mereka, dengan kata lain model hubungan openness to experience dengan innovative work behavior dalam penelitian ini tidak tergantung dengan adanya moderator ambidextreous organizational culture.

Peran ambidextrous organizational culture yang tidak berfungsi pada penelitian ini dapat disebabkan oleh partisipan penelitian yang berasal dari berbagai macam jenis pekerjaan dan organisasi yang berbeda-beda. Semakin heterogen jenis pekerjaan, akan semakin berbeda-beda pula persepsi karyawan terhadap budaya organisasi yang dimiliki oleh perusahaannya. Hal ini sejalan dengan teori yang menyebut bahwa setiap organisasi memiliki culture yang berbeda dimana di dalamnya mengandung kebijakan, tujuan, shared meanings yang akan berpengaruh pada persepsi dan pola berpikir karyawannya (Schein \& Schein, 2016). Seharusnya, peneliti mempertimbangkan adanya konteks yang berbeda pada organisasi yang berbeda yang berpotensi menghasilkan persepsi yang berbeda pada setiap partisipan penelitian.

Hasil dari penelitian ini mendukung temuan dari Olakitan (2011), yang menggunakan model kepribadian Big five untuk mengukur kepribadian dan menyatakan bahwa kepribadian merupakan salah satu faktor yang membentuk perilaku kerja inovatif pada karyawan. Lebih lanjut disimpulkan 3 sifat kepribadian yaitu extraversion, agreeableness dan conscientiousness berhubunngan positif dengan inovasi teknologi, sedangkan 
conscientiousness, openness to experience, extraversion, dan emotional stability berhubungan positif dengan perilaku kerja inovatif pada karyawan.

Mengacu pada beberapa penjelasan di atas, penelitian memperkuat temuan studi yang sebelumnya yang menghubungkan antara faktor internal yang menjadi prediktor dan cukup konsisten dalam membentuk perilaku kerja yang inovatif. Selain itu, penelitian ini juga membuktikan bahwa individu dengan kepribadian openness to experience yang tinggi berkontribusi besar terhadap perilaku inovatif (Javed et al., 2019). Penelitian ini juga menambahkan informasi mengenai variabelvariabel lain yang di analisis yaitu bidang pekerjaan, masa kerja, dan pendidikan terakhir yang memiliki hubungan kuat terhadap munculnya perilaku inovatif. Dapat dikatakan bahwa semakin lama seseorang bekerja akan semakin memungkinkan untuk memunculkan perilaku inovatif. Temuan ini sejalan dengan hasil penelitian Etikariena (2019) yang menyebutkan bahwa masa kerja dan pendidikan terakhir merupakan salah satu faktor yang dapat menjadi prediktor performa kerja karyawan, termasuk juga untuk menampilkan perilaku inovatif.

Selain penjelasan di atas, penelitian ini memiliki kontribusi di bidang bidang psikologi industri dan organisasi yang belum banyak menguji peran variabel ambidextreous organizational culture terhadap perilaku kerja inovatif. Penelitian ini dapat menjadi referensi dan literasi terkait variabel yang dapat mendorong munculnya perilaku kerja inovatif. Penelitian selanjutnya diharapkan dapat menjelaskan variabel-variabel lain yang menjadi prediktor perilaku kerja inovatif dan mempertimbangkan saran penelitian untuk mengambil sampel dari salah satu organisasi agar peran dari variabel ambidextrous organization culture dapat berfungsi.

Hasil penelitian ini dapat memberikan gambaran pada berbagai perusahaan dalam melakukan rekrutmen pada karyawan baru untuk mempertimbangkan calon karyawan yang memiliki kepribadian yang openness. Pelamar yang memiliki kualifikasi kepribadian openness diharapkan ketika bekerja mereka bisa memunculkan perilaku inovatif. Selain itu, perusahaan juga dapat memperhatikan adanya budaya ambidextrous organizational culture yang terdiri dari shared vision dan organizational diversity untuk dapat memunculkan perilaku inovatif pada karyawannya.

Secara keseluruhan, masih terdapat beberapa hal yang menjadi keterbatasan dalam penelitian ini. Salah satunya adalah terkait dengan pengambilan sampel. Dalam penelitian ini, peneliti melibatkan banyak organisasi dari berbagai macam latar belakang dan culture sehingga peran dari ambidextrous organizational culture tidak berfungsi. Dengan karakteristik sampel yang berbeda kemungkinan terdapat perbedaan persepsi dalam melihat budaya ambidextrous di dalam 
organisasi yang menyebabkan nilai organizational diversity dan nilai shared vision tidak ada tanggapan secara seragam oleh setiap karyawan. Partisipasi karyawan dari berbagai organisasi yang berbeda merupakan batasan potensial karena peneliti tidak dapat mengontrol semua perbedaan antar organisasi yang dapat berdampak pada hasil penelitian. Hal ini menjadi salah satu kelemahan dalam penelitian karena seharusnya penelitian dilakukan dalam satu organisasi dimana konteks budaya yang diterapkan dalam organisasi akan dapat terlihat. Hal ini sejalan dengan pendapat Schein \& Schein (2016) yang menyatakan bahwa karyawan dalam organisasi yang sama akan memiliki asumsi yang sama, termasuk bagaimana mereka menanggapi budaya organisasi yang diterapkan di perusahaannya.

Pada penelitian yang selanjutnya, perlu mempertimbangkan variabel lain sebagai moderator misalnya leadership, seperti pada penelitian Javed et al (2019) yang menunjukkan kepemimpinan etis yang menguatkan hubungan antar openness to experience dengan perilaku kerja inovatif. Organisasi yang memiliki kepemimpinan etis yang tinggi akan menyebabkan karyawan lebih fleksibel dalam bekerja dan termotivasi untuk menjadi lebih terbuka dan memunculkan perilaku yang inovatif. Variabel lain yang dapat dipertimbangkan sebagai moderator dalam penelitian adalah organizational tenure (Woods et al., 2018); ambidextrous leadership (Rosing
\& Zacher, 2017); psychological empowerment; transformational leadership (Liu et al., 2019).

Penelitian ini hanya mengambil salah satu tipe kepribadian yaitu openness to experience sebagai prediktor dari perilaku kerja inovatif. Penelitian selanjutnya diharapkan untuk menguji tipe kepribadian lain dalam big five seperti conscientiousness untuk membuktikan studi sebelumnya yang menyatakan bahwa selain openness, tipe conscientiousness juga merupakan tipe kepribadian yang cukup konsisten dalam memprediksi perilaku inovatif (Etikariena, 2019; Olakitan, 2011). Selain itu, penelitian selanjutnya juga dapat berfokus pada inovasi pada organisasi (Woods et al., 2018; Yesil \& Sozbilir, 2013).

Meskipun peneliti telah berusaha untuk mengurangi bias dalam pengambilan data, namun penelitian ini menggunakan desain cross-sectional yang dilakukan dalam satu waktu, sehingga penelitian selanjutnya sebaiknya mempertimbangkan untuk menggunakan desaian penelitian time lagged untuk mengantisipasi akan adanya common method bias. Selain itu, karena adanya kelemahan dalam alat ukur yang dikembangkan oleh Wang \& Rafiq (2014), penelitian selanjutnya dapat menggunakan alat ukur lain dalam mengukur ambidextrous organization culture dengan multidimensi sehingga tidak hanya menekankan hasil persepsi saja melainkan membuat kategorisasi untuk beberapa karakteristik budaya sehingga mampu menggambarkan budaya yang 
ambidextrous dalam organisasi (Lee et al., 2019).

Kelemahan lain penelitian adalah alat ukur menggunakan self report sehingga memungkinkan partisipan untuk memberikan jawaban yang disukai secara sosial atau dapat menimbulkan social desirability. Pengukuran dengan self report memiliki masalah potensial lainnya yaitu mungkin tidak akurat untuk melihat kinerja inovatif karyawan (Rosing \& Zacher, 2017). Meskipun beberapa penelitian menunjukkan bahwa self-ratings pada perilaku kerja inovatif berhubungan positif dengan penilaian lain atau indikator objektif dalam perilaku kerja inovatif, penelitian di masa depan harus mencoba untuk memasukkan lebih dari satu sumber informasi mengenai perilaku kerja inovatif.

\section{Simpulan}

Mengacu pada hasil dan pembahasan yang telah peneliti sampaikan pada bagian yang sebelumnya, maka dapat disimpulkan bahwa kepribadian openness to experience dan ambidextrous organizational culture berhubungan positif signifikan dengan perilaku kerja karyawan. Hal ini menunjukkan bahwa kepribadian openness to experience dan ambidextrous organizational culture merupakan prediktor dari perilaku inovatif sehingga dapat dipertimbangkan oleh organisasi untuk mengembangkan program inovasi di organisasi. Selain itu, faktor seperti bidang pekerjaan, tenure, dan posisi seseorang dalam organisasi juga memiliki hubungan signifikan yang dapat berpengaruh pada perilaku inovatif karyawan. Sebaliknya, faktor jenis kelamin ternyata tidak memiliki hubungan signifikan dengan perilaku inovatif sehingga tidak akan menghambat program inovasi yang akan dilakukan oleh organisasi.

\section{Saran}

Peneliti selajutnya dapatmempertimbangkan variabel lain yang menguatkan hubungan openness to experience dengan perilaku kerja inovatif.

\section{Referensi}

Blickle, G., Meurs, J. A., Wihler, A., Ewen, C., Plies, A., \& Günther, S. (2013). The interactive effects of conscientiousness, openness to experience, and political skill on job performance in complex jobs: The importance of context. Journal of Organizational Behavior, 34(8), 11451164. https://doi.org/10.1002/job.1843

Büschgens, T., Bausch, A., \& Balkin, D. B. (2013). Organizational culture and innovation: A meta-analytic review. Journal of Product Innovation Management, 30(4), 763781. https://doi.org/10.1111/ jpim.12021

Costa, P. T., \& McCrae, R. R. (1992). Normal personality assessment in clinical practice: The NEO personality inventory. Psychological Assessment, 4(1), 5-13. https: // do i.org/10.1037/10403590.4.1.5

de Jong, J., \& den Hartog, D. (2010). Measuring innovative work behaviour. Creativity and Innovation Management, 19(1), 2336. https://doi.org/10.1111/j.14678691.2010.00547.x

DeYoung, C. G., Quilty, L. C., Peterson, J. B., \& Gray, J. R. (2014). Openness to experience, intellect, and cognitive 
ability.Journal of Personality Assessment, 96(1), 46-52. https://doi.org/10.1080/ 00223891.2013 .806327

Etikariena, A. (2019). Perbedaan perilaku kerja inovatif berdasarkan karakteristik individu karyawan. Jurnal Psikologi, 17(2), 107. https://doi.org/10.14710/ jp.17.2.107-118

Gibson, C. B., \& Birkinshaw, J. (2004). The antecedents, consequences, and mediating role of organizational ambidexterity. Academy of Management Journal, 47(2), 209-226. https://doi.org/ $10.5465 / 20159573$

Janssen, O. (2000). Job demands, perceptions of effort-reward fairness and innovative work behaviour. Journal of Occupational and Organizational Psychology, 73(3), 287-302. https://doi.org/10.1348/ 096317900167038

Javed, B., Naqvi, S. M. M. R., Khan, A. K., Arjoon, S., \& Tayyeb, H. H. (2019). Impact of inclusive leadership on innovative work behavior: The role of psychological safety. Journal of Management \& Organization, 25(1), 117-136. https:// doi.org/10.1017/jmo.2017.3

Jiangtao Shi. (2012). Influence of passion on innovative behavior: An empirical examination in Peoples Republic of China. AFRICAN JOURNAL OF BUSINESS MANAGEMENT, 6(30). https://doi.org/ 10.5897/AJBM11.2250

Jong, J. de, \& Hartog, D. Den. (2007). Innovative work behavior: Measurement and validation. EIM Business and Policy Research, 127.

Khan, S. J., \& Mir, A. A. (2019). Ambidextrous culture, contextual ambidexterity and new product innovations: The role of organizational slack and environmental factors. Business Strategy and the Environment, 28(4), 652-663. https:// doi.org/10.1002/bse.2287

Lau, E. Y. Y., Wong, M. L., Rusak, B., Lam, Y. C., Wing, Y. K., Tseng, C. huei, \& Lee, T. M. C.
(2019). The coupling of short sleep duration and high sleep need predicts riskier decision making. Psychology and Health, 34(10), 1196-1213. https:// d o i . o r g / $10.1080 /$ 08870446.2019.1594807

Lee, J. Y., Seo, Y., Jeung, W., \& Kim, J. (2019). How ambidextrous organizational culture affects job performance: A multilevel study of the mediating effect of psychological capital. Journal of Management \& Organization, 25(6), 860-875. https://doi.org/10.1017/ jmo.2017.38

Liu, Y., Wang, W., \& Chen, D. (2019). Linking ambidextrous organizational culture to innovative behavior: A moderated mediation model of psychological empowerment and transformational leadership. Frontiers in Psychology, 10(2192). https://doi.org/10.3389/ fpsyg.2019.02192

Madrid, H. P., Patterson, M. G., Birdi, K. S., Leiva, P. I., \& Kausel, E. E. (2014). The role of weekly high-activated positive mood, context, and personality in innovative work behavior: A multilevel and interactional model. Journal of Organizational Behavior, 35(2), 234256. https://doi.org/10.1002/job.1867

Olakitan, O. 0. (2011). An examination of the impact of selected personality traits on the innovative behaviour of entrepreneurs in Nigeria. International Business and Management, 3(2), 112-121. https:// d o i . o r g / 10.3968 / j.ibm.1923842820110302.075

Palangkaraya, A., Stierwald, A., Webster, E., \& Jensen, P. H. (2010). Examining the characteristics of innovative firms in Australia. https:// www.swinburne.edu.au/media / swinburneeduau/research/docs/word/ Examining_the_Characteristics_of_Innovative_ Firms_in_Australia_2010.pdf

Perkonigg, A., Goodwin, R. D., Fiedler, A., Behrendt, S., Beesdo, K., Lieb, R., \& Wittchen, H. U. (2008). The natural course of cannabis use, abuse and 
dependence during the first decades of life. Addiction, 103(3), 439-449. https:/ / do i org / $10.1111 /$ j.1360 0443.2007.02064.x

Rosing, K., \& Zacher, H. (2017). Individual ambidexterity: The duality of exploration and exploitation and its relationship with innovative performance. European Journal of Work and Organizational Psychology, 26(5), 694-709. https:// d o i . o r g / 10 . 10080 / 1359432X.2016.1238358

Ryan, R. M., Huta, V., \& Deci, E. L. (2008). Living well: A self-determination theory perspective on eudaimonia. Journal of Happiness Studies, 9(1), 139-170. https:/ /doi.org/10.1007/s10902-006-9023-4

Schein, E. H., \& Schein, P. A. (2016). Organizational culture and leadership (5th ed.). The Jossey-Bass Business \& Management Series.

Scott, S. G., \& Bruce, R. A. (1994). Determinants of innovative behavior: A path model of individual innovation in the workplace. Academy of Management Journal, 37(3), 580-607. https://doi.org/10.2307/ 256701

Wang, C. L., \& Rafiq, M. (2014). Ambidextrous organizational culture, contextual ambidexterity and new product innovation: A comparative study of UK and Chinese high-tech firms. British Journal of Management, 25(1), 58-76. https://doi.org/10.1111/j.14678551.2012.00832.x

West, M. A., \& Farr, J. L. (1989). Innovation at work: Psychological perspectives. Social Behaviour, 4(1), 15-30.
Woods, S. A., Mustafa, M. J., Anderson, N., \& Sayer, B. (2018). Innovative work behavior and personality traits. Journal of Managerial Psychology, 33(1), 29-42. https://doi.org/10.1108/JMP-01-20170016

Wortman, J., Lucas, R. E., \& Donnellan, M. B. (2012). Stability and change in the Big Five personality domains: Evidence from a longitudinal study of Australians. Psychology and Aging, 27(4), 867-874. https://doi.org/ $10.1037 / \mathrm{a} 0029322$

Yesil, S., \& Sozbilir, F. (2013). An empirical investigation into the impact of personality on individual innovation behaviour in the workplace. Procedia Social and Behavioral Sciences, 81, 540551. https://doi.org/10.1016/ j.sbspro.2013.06.474

Yuan, F., \& Woodman, R. W. (2010). Innovative behavior in the workplace: The role of performance and image outcome expectations. Academy of Management Journal, 53(2), 323-342. h t tp s: / / doi.org / 10.5465 / amj.2010.49388995

Zhou, K. Z., Yim, C. K. (Bennett), \& Tse, D. K. (2005). The effects of strategic orientations on technology- and marketbased breakthrough innovations. Journal of Marketing, 69(2), 42-60. h ttp s: / / doi.org/10.1509/ jmkg.69.2.42.60756

Received 7 January 2021 Revised 5 May 2021 Accepted 31 July 2021 
